\title{
Yatırım Gelişme Yolu Yaklaşımı Üzerine Bir Yakınsama Analizi
}

\author{
Şekip YAZGAN (https://orcid.org/0000-0003-1006-668X), Department of Economics, A ̈̆rı İbrahim Çeçen \\ University, Turkey; e-mail: syazgan@agri.edu.tr
}

Reşat CEYLAN (https://orcid.org/0000-0003-3727-6644), Department of Economics, Pamukkale University, Turkey; e-mail: rceylan@pau.edu.tr

Muhammed Ş̈̈krü MOLLAVELIOĞLU (https://orcid.org/0000-0002-0633-4525), Department of Economics,

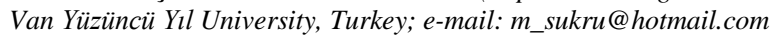

\section{A Convergence Analysis on the Investment Development Path Approach}

\begin{abstract}
This study, which examines whether the investment development path curves of the developed and developing countries show convergence behaviour in the 1970-2018 period, has two main objectives. The first is to analyse whether foreign direct investment eliminates the development differences between countries based on the investment development path approach. Using the nonlinear unit root tests developed recently, the second is to investigate whether the convergence behaviour of the investment development path curves is affected by macroeconomic shocks. According to the findings, these countries' investment development path curves exhibit a non-linear convergence behaviour, and therefore the convergence process is affected by macroeconomic shocks.

Keywords

JEL Classification Codes :

Investment Development Path Approach, Convergence Hypothesis, Non-Linear Unit Root Tests.

Öz

Gelişmiş ve gelişmekte olan ülkelere ait yatırım gelişme yolu eğrilerinin 1970-2018 döneminde yakınsama davranışı gösterip göstermediğinin incelendiği bu çalışmanın iki temel amacı bulunmaktadır. Bunlardan birincisi, yatırım gelişme yolu yaklaşımından hareketle küreselleşme sürecinin temel araçlarından olan doğrudan yabancı sermaye yatırımlarının ülkeler arasındaki gelişmişlik farklılıklarını ortadan kaldırıp kaldırmadığını analiz etmektir. İkincisi ise, son dönemlerde geliştirilen doğrusal olmayan birim kök testlerini kullanarak, yatırım gelişme yolu eğrilerinin yakınsama davranışının ortaya çıkan makroekonomik şoklardan etkilenip etkilenmediğini araştırmaktır. Elde edilen bulgular, söz konusu ülkelerin yatırım gelişme yolu eğrilerinin doğrusal olmayan bir yapıda yakınsama davranışı sergilediğini ve dolayısıyla yakınsama sürecinin makroekonomik şoklardan etkilendiğini göstermektedir.
\end{abstract}

Anahtar Sözcükler $\quad$ : Yatırım Gelişme Yolu Yaklaşımı, Yakınsama Hipotezi, Doğrusal Olmayan Birim Kök Testleri. 
Yazgan, Ş. \& R. Ceylan \& M.Ş. Mollavelioğlu (2021), "Yatırım Gelişme Yolu

Yaklaşımı Üzerine Bir Yakınsama Analizi”, Sosyoekonomi, 29(48), 489-510.

\section{Giriş}

İktisadi gelişme ile doğrudan yabancı sermaye yatırımları (DYSY) arasındaki sistematik ilişki Yatırım Gelişme Yolu Yaklaşımı (YGYY) ile ortaya konulmaktadır (Dunning, 1981; Dunning \& Narula, 1996; Narula, 1996). YGYY, iktisadi gelişmeyi yapısal dönüşümün bir başarısı olarak görmekle birlikte bu ekonomik ve sosyal dönüşümün ülkeye giren (FDI) ve ülkeden çıkan (ODI) doğrudan yabancı sermaye yatırımlarının davranışlarıyla sistematik bir ilişki içerisinde olduğunu ileri sürmektedir (Duran \& Ubeda, 2001: 1; Narula \& Guimon, 2010: 6). YGYY'na göre, ülkenin iktisadi gelişme düzeyi arttıkça yerli ve yabancı şirketlerin karşılaştı̆̆ yatırım girişlerini ve çıkışlarını etkileyen yapısal bir değişiklik meydana gelmekte ve bu da ülkenin iktisadi yapısını değiştirmektedir. Bu yönüyle, YGYY, ülkenin gayri safi yurtiçi hasıla / kişi başına gayri safi yurtiçi hasıla ile ifade edilen gelişmişlik düzeyi ile ülkeye giren ve ülkeden çıkan doğrudan yabancı sermaye farkıyla ifade edilen net doğrudan yatırım pozisyonu arasındaki dinamik ve zamanlar arası bir ilişkiyi ortaya koymaktadır (Fonseca, vd., 2016: 5). Bu yönüyle YGYY, iktisadi gelişme bağlamında ODI ve FDI arasında dolaylı bir ilişki olduğunu ileri sürmektedir (Apergis, 2009: 21).

Dunning (1980) tarafından geliştirilen ve DYSY'yi çok uluslu firmaların eş zamanlı olarak sahip olduğu sahiplik, içselleştirme ve konumsal üstünlükler olmak üzere üç temel üstünlük ile açıklayan Eklektik Teori üzerine kurulan YGYY, söz konusu üstünlükler arasındaki üç yönlü etkileşim ile bir ülkenin iktisadi gelişmenin beş farklı aşamasını deneyimleme eğiliminde olduğunu savunmaktadır. Buna göre, YGYY'nın ilk aşaması hem ODI hem de FDI'nın çok düşük seviyelerde olduğu en az gelişmiş ülkelerin durumunu yansıtmaktadır. Bu aşamada ülke genellikle sınırlı bir iç pazarın, altyapı eksikliğinin, düşük vasıflı işgücünün ve uygunsuz kurumların ve hükümet politikalarının birleşimi nedeniyle sahiplik veya konumsal üstünlüklerden yoksun durumda bulunmaktadır. İkinci aşamada, ülkenin çokuluslu şirketler nazarında çekiciliğini artıran konumsal üstünlüklere özgü avantajlarını geliştirmesi sayesinde ODI önemli ölçüde büyümektedir. Ancak bu aşamada ülkedeki yerli firmaların sahiplik avantajlarının hala zayıf bir durumda olması nedeniyle ülkenin ODI seviyesi düşük seviyede bulunmakta ve ülkenin net dış yatırım pozisyonunun aldığı negatif değerler artmaktadır. Üçüncü aşamada, ülkede bulunan yerli firmalar yabanc1 firmalara kıyasla daha rekabetçi hale geldikçe ülkedeki ODI seviyesi artmaya başlamakla birlikte ülkenin net dış yatırım pozisyonu hala negatif değerler almaya devam etmektedir. Dördüncü aşamada ise sahiplik üstünlüklerine bağlı olarak artan ODI nedeniyle ülkenin net dış yatırım pozisyonu ilk kez pozitif değerler almaya başlamaktadır. Son olarak gelişmiş ülkelerdeki durumu yansıtan beşinci aşamada ülkenin net dış yatırım pozisyonu pozitif veya negatif değerlere sahip olmakla birlikte sıfır değeri civarında kararsız bir denge durumunda bulunmaktadır. Bu kapsamda, merkezini ODI ve FDI arasındaki dinamik ilişkinin oluşturduğu YGYY, bir ülkenin net doğrudan yabancı yatırım pozisyonunun söz konusu ülkenin gelişmişlik seviyesi ile ilişkili olduğunu ve ülkenin net doğrudan yatırım pozisyonunu ifade eden Yatırım Gelişme Yolu Eğrisinin "U” biçiminde olduğunu ifade etmektedir (Narula \& Guimon, 2010). Buna göre en az gelişmiş ülkeler ve gelişmekte olan ülkeler tipik olarak yatırım gelişme yolunun sırasıyla birinci ve ikinci veya üçüncü 
Yazgan, Ş. \& R. Ceylan \& M.Ş. Mollavelioğlu (2021), "Yatırım Gelişme Yolu

Yaklaşımı Üzerine Bir Yakınsama Analizi”, Sosyoekonomi, 29(48), 489-510.

aşamasında yer alırlarken, gelişmiş ülkeler ise yatırım gelişme yolunun dördüncü veya beşinci aşamasında bulunmaktadır (Gorynia vd., 2019: 576). Başka bir ifadeyle YGYY'na göre, ülkenin iktisadi gelişmişlik seviyesi arttıkça, net doğrudan yatırım pozisyonu bakımından ev sahibi ülke konumundan kaynak ülke konumuna doğru evrilmektedir. Ancak burada iki hususu vurgulamak gerekmektedir. Birinci husus, YGYY'nda ifade edilen söz konusu bu beş aşamanın her biri birer gösterge niteliğinde bulunmaktadır. İkinci husus ise, ülkelerin aşamalar içerisinde ve aşamalar arasındaki ilerlemeleri "otomatik" bir şekilde gerçekleşmemekte ve ülkeler yatırım gelişme yolunun aşamaları arasında hem ileri hem de geri yönlü bir hareket içerisinde olabilmektedir (Narula \& Guimon, 2010: 6-7).

$\mathrm{Bu}$ bağlamda söz konusu çalışmada, gelişmiş ve gelişmekte olan ülkelerin net doğrudan yatırım pozisyonlarını temsil eden yatırım gelişme yolu eğrileri için yakınsama hipotezinin geçerliliği ampirik olarak incelenmektedir. Yakınsama hipotezi Neo-klasik Büyüme Modelinin en önemli çıkarımlarından biridir ve son kırk yıldır iktisadi büyüme literatürünün en çok tartışılan konuları arasında yer almaktadır. Barro (1991), Barro ve Salai Martin (1992) ve Bernard ve Durlauf (1995)'e göre yakınsama hipotezi, sermayenin marjinal verimliliğinin yüksek olduğu sermaye fakiri ülkelerde büyüme hızının, sermayenin marjinal verimliliğinin düşük olduğu sermaye zengini ülkelerden daha yüksek olacağ argümanına dayanmaktadır. Ayrıca, ülkelerin başlangıç koşullarının ve yapısal özelliklerinin özdeş olması durumunda mutlak yakınsama, başlangıç koşulları ve yapısal özelliklerinin farklı olması durumunda ise koşullu yakınsama çıkarımı yapılabilmektedir. Yakınsama hipotezine göre ülkeler arası gelir yakınsamasının üç temel sebebi bulunmaktadır. Bu sebeplerin sırasıyla; ülkeler arasında teknoloji transferlerini ifade eden teknolojik yayılım, kapalı ekonomi koşulları altında sermaye faktöründe azalan getirilerin yakınsama sürecini ortaya koyacağını savunan Neo-klasik büyüme modeli ve ülkeler arasındaki mal ve faktör hareketliliği önündeki engellerin kaldırılması anlamına gelen küreselleşme olgusu olduğu ifade edilmektedir (Ceylan, 2010: 50). Yakınsama hipotezi küreselleşme bağlamında değerlendirildiğinde, DYSY küreselleşme sürecini hızlandırarak süreç içerisinde önemli bir rol oynamaktadır. DYSY, sermaye birikimini artırmak ve yeni teknikler ve bilgi aktarımı yapmak yoluyla ülke ekonomileri için büyümeyi ve istihdamı artırmayı teşvik eden bir araç olarak görülmektedir. Sahip oldukları sınırlı sermaye ve teknik kaynakları nedeniyle DYSY, özellikle gelişmekte olan ülkeler için daha da fazla önem arz etmektedir (Kılıçaslan vd., 2019: 2).

1970'li yıllardan günümüze küresel düzeyde ODI ve FDI'nın gelişmiş ve gelişmekte olan ülkeler arasındaki dağılımında önemli değişiklikler olduğu görülmektedir. Gelişmekte olan ülkelerin FDI ve özellikle ODI bağlamında küresel doğrudan yatırımlardan aldıkları paylar dikkat çekici bir biçimde artmaktadır. Küresel düzeyde doğrudan yatırımlarda meydana gelen söz konusu bu değişmelerin gelişmiş ve gelişmekte olan ülke gruplarının net doğrudan yatırım pozisyonlarının yani başka bir ifadeyle yatırım gelişme yolu eğrilerinin birbirlerine yakınsayıp yakınsamadığı sorusunu gündeme getirmektedir. $\mathrm{Bu}$ kapsamda çalışmada, ODI ve FDI boyutuyla Dünya'daki DYSY'nın tamamını kapsayan ve dünyanın farklı kıtalarında konumlanan ve gelişmiş ve gelişmekte olan ülkeler olarak toplulaştırılan ülke grupları için yatırım gelişme yolu eğrileri için yakınsama hipotezinin geçerliliği, 
Yazgan, Ş. \& R. Ceylan \& M.Ş. Mollavelioğlu (2021), "Yatırım Gelişme Yolu

Yaklaşımı Üzerine Bir Yakınsama Analizi”, Sosyoekonomi, 29(48), 489-510.

Bernard ve Durlauf (1995) tarafından ortaya konan yakınsamanın zaman serisi analizi kapsamında KSS (Kapetanios vd., 2003), KRUSE (Kruse, 2011) ve SOR (Shahbaz vd., 2019) doğrusal olmayan birim kök testleri kullanılarak 1970-2018 dönemi için ekonometrik olarak incelenmektedir. Örneklem periyotunun, dünya ekonomisi açısından siyasi, ekonomik ve sosyal yönlerden birçok değişimin yaşandığ́ (Bretton-Woods sisteminin çökmesi, sermaye akımlarının serbestleşmesi, petrol şoklarının yaşanması gibi) bir dönemi kapsaması, yatırım gelişme yolu eğrilerinin doğrusal olmama davranışı sergileyebileceklerine işaret etmektedir. Yatırım gelişme yolu eğrilerinin doğrusal olduğu hipotezin, reddedilmesi sonucunda, yakınsama sürecinin analizinde yukarıda sözü edilen birim kök testleri kullanılabilmektedir. Söz konusu bu analiz yoluyla yakınsama sürecinin makroekonomik şoklardan etkilenip etkilenmediği hususunun belirlenebileceği değerlendirilmektedir.

Çalışmanın geri kalanı aşağıdaki gibi tasarlanmaktadır: İkinci bölümde, çalışmanın teorik altyapısını oluşturan YGYY ve söz konusu yaklaşım kapsamındaki ampirik literatür özetlenmekte ve çalışmanın literatürdeki konumu belirtilmektedir. Üçüncü bölümde, çalışmada kullanılan veri seti tanıtılmakta ve ekonometrik metodoloji açıklanmaktadır. Dördüncü bölümde, gelişmiş ve gelişmekte olan ülkelerin yatırım gelişme yolu eğrileri için yakınsama hipotezinin geçerliliği zaman serisi analizi kapsamında doğrusal olmayan birim kök testleriyle 1970-2018 dönemi için ekonometrik olarak incelenmekte ve elde edilen bulgular sunulmaktadır. Çalışma araştırma bulgularının tartışıldığı sonuç bölümüyle tamamlanmaktadir.

\section{Yatırım Gelişme Yolu Yaklaşımı: Teorik Çerçeve ve Ampirik Literatür}

YGYY'nın üzerine kurulduğu Eklektik teori, DYSY'yi çok uluslu firmaların eş zamanlı sahip oldukları üç temel üstünlük ile açıklamaktadır. Söz konusu üstünlüklerden birincisi, firmaların sahipliğinde olan ve maddi olmayan varlıklara dayalı patent, yönetim ve pazarlama becerisi, marka değeri gibi unsurların sahipliğinden kaynaklanan sahiplik üstünlügüüur. Eklektik Teori'de ifade edilen ikinci ve üçüncü üstünlükler ise sirasıyla, firmaların sahiplik üstünlüklerini uluslararası pazarlardaki kendi kontrolündeki birimlerde kullanmasını ifade eden içselleştirme ve yatırımların yapılacağı ülkenin seçimini etkileyen konumsal üstünler olarak belirtilmektedir (Kılıçaslan vd., 2018: 36-37).

Bu kapsamda Eklektik Teori'nin dinamik bir versiyonu olan ve makroekonomik bir yaklaşım olan YGYY, sahiplik, içselleştirme ve konumsal üstünlükler arasındaki üç yönlü etkileşim ile ülkelerin ekonomik gelişmişlik seviyeleri ve ülkelerin karşı karşıya olduğu DYSY arasında beş aşamalı bir ilişki öngörmektedir. Birinci aşamada, sanayileşme sürecinin başında olan ve kişi başına düşen gelir düzeyi çok düşük seviyede olan ülkenin rekabetçi üstünlüğü, ülkenin sahip olduğu doğal kaynaklara bağlı olarak ortaya çıkmaktadır. Birinci aşamada, ülke firmalarının sahiplik üstünlüklerini geliştirememeleri ve ülkenin sahip olduğu altyapı, nitelikli emek, talep gibi unsurların yurt dışındaki yatırımcılar için cazip olmaması nedeniyle ülkenin yurt dışında doğrudan yabancı sermaye yatırımları ve ülkeye yurt dışından gelen doğrudan yabancı sermaye girişleri de oldukça düşük bir seviyede 
bulunmaktadır. $\mathrm{Bu}$ aşamada ülkenin net doğrudan yabancı yatırım pozisyonu negatif değerler almaktadır. İkinci aşamada, ülkenin sahip olduğu sanayi, emek yoğun ve temel tüketim mallarına yönelik bir yapıda bulunmaktadır. Bu yapıya bağlı olarak gelişen ülke ekonomisinde, eğitim, sağlık, ulaştırma alanlarına daha fazla kaynak ayrılması sonucunda yatırım ortamının iyileşmesi nedeniyle birinci aşamayla kıyaslandığında ikinci aşamada ülkenin, daha fazla doğrudan yabancı sermaye yatırımı almaya başladığı görülmektedir. Ülkeye gelen doğrudan yabancı sermaye yatırımları genellikle iç pazar için ithal ikame üretim yapmakta veya ülkenin sahip olduğu doğal kaynakları ihraç pazarları için değerlendirmeyi amaçlamaktadır. Bu aşamada ülke firmalarının, ülkede gelişen sanayi faaliyetleri ve ülkeye gelen yabancı doğrudan yatırımların etkisiyle sahiplik üstünlüklerini artırdıkları görülmektedir. Buna karşın ikinci aşamada da ülke firmalarının yurt dışı doğrudan sermaye yatırımları ihmal edilebilir bir düzeyde bulunmakta ve ülkenin net doğrudan yabancı yatırım pozisyonu negatif değerler almaya devam etmektedir. Üçüncü aşamada ülkenin net doğrudan yabancı yatırım pozisyonu yine negatif değerler almakta ancak ülkeye gelen doğrudan yabancı yatırım miktarında azalma ve ülke firmalarının gerçekleştirdikleri doğrudan yatırım miktarında ise artışlar meydana geldiği görülmektedir. $\mathrm{Bu}$ aşamada birinci ve ikinci aşamalardan farklı olarak ülke firmaları kendi sahiplik üstünlüklerini geliştirmekte ve ülkede faaliyet gösteren yabancı firmalarla rekabet edebilmektedir. Bu aşamadaki ülkeler, gelişmekte olan veya yeni sanayileşen ülkeler olarak sınıflandırılabilmektedir. Dördüncü aşamada ise, ilk kez ülkenin yurtdışında yaptığ doğrudan yatırım miktarı ülkeye gelen doğrudan yatırım miktarına eşitlenmekte ve hatta bu düzeyin üzerine çıkmaktadır. Başka bir ifadeyle dördüncü aşamada ülke net doğrudan yatırım pozisyonu bakımından kaynak ülke konumuna ulaşmaktadır. Bu aşamada ülke firmaları dünya pazarlarında da rekabetçi üstünlüklere sahip durumda bulunmakta, dünyanın çok farklı coğrafyalarında faaliyet gösterebilmekte ve dünyadaki farklı ülkeler tarafından geliştirilen teknolojilerden istifade edebilmektedir. Beşinci aşamada, ülkenin net doğrudan yatırım pozisyonu sıfır düzeyinde bulunmakta ve bu düzeyde döviz kuru ve konjonktür dalgalanmalarına bağlı olarak dönemsel dalgalanmalar göstermektedir. Günümüzün gelişmiş ülkelerinin yatırım gelişme yolunun beşinci aşamasında oldukları değerlendirilmektedir (Dunning \& Narula, 1996: 2-7; Kılıçaslan vd., 2018: 50-51).

Yatırım Gelişme Yolunun yukarıda ifade edilen beş aşaması ile ilgili açıklamalar neticesinde ülkenin net doğrudan yatırım pozisyonundaki değişimleri ortaya koyan Yatırım Gelişme Yolu Eğrisi aşağıda Şekil 1'de gösterilmektedir. Şekil 1'de yatay eksende gayri safi yurtiçi hasıla (GSYİH) dikey eksende ise net dış yatırım pozisyonu (NDYP) bulunmaktadır. Şekil 1'de gayri safi yurt içi hasıla eğrisine paralel olarak çizilen doğrunun, ülkeden giden ve ülkeye gelen yabancı doğrudan yatırımların birbirine eşit olduğu (ODI=FDI), başka bir ifade ile net doğrudan yabancı yatırım pozisyonunun yani ODI ve FDI farkının sıfıra eşit olduğu eşik seviyesini gösterdiği kabul edildiğinde, Yatırım Gelişme Yolunun beş aşamasının her birinde ülkeden giden ve ülkeye gelen DYSY'nın birbirinden farklı miktarlarda gerçekleştiği ve buna bağlı olarak da ülkenin net doğrudan yabancı yatırım pozisyonunun negatif veya pozitif değerler aldığı görülmektedir. Bu kapsamda net doğrudan yabancı yatırım pozisyonu, ilk üç aşamada negatif, dördüncü aşamada pozitif değerler 
almakta; beşinci aşamada ise sıfır değerinin etrafında dalgalanmaktadır. Başka bir ifadeyle, Şekil 1'de gösterilen Yatırım gelişme yolu eğrisi ile ortaya konan kişi başı net doğrudan yabancı yatırım pozisyonu ile gayri safi yurt içi hasıla arasındaki ilişkinin, ilk üç aşamada "U” şeklinde, dördüncü aşamaya geçilmesiyle de "ters U" seklinde bir biçim almakta ve beşinci aşamada ise geleneksel gelişme yolu olarak da ifade edilen eşik değerinin etrafinda dalgalanmaktadır.

\section{Şekil: 1 \\ Yatırım Gelişme Yolu Ĕgrisi}

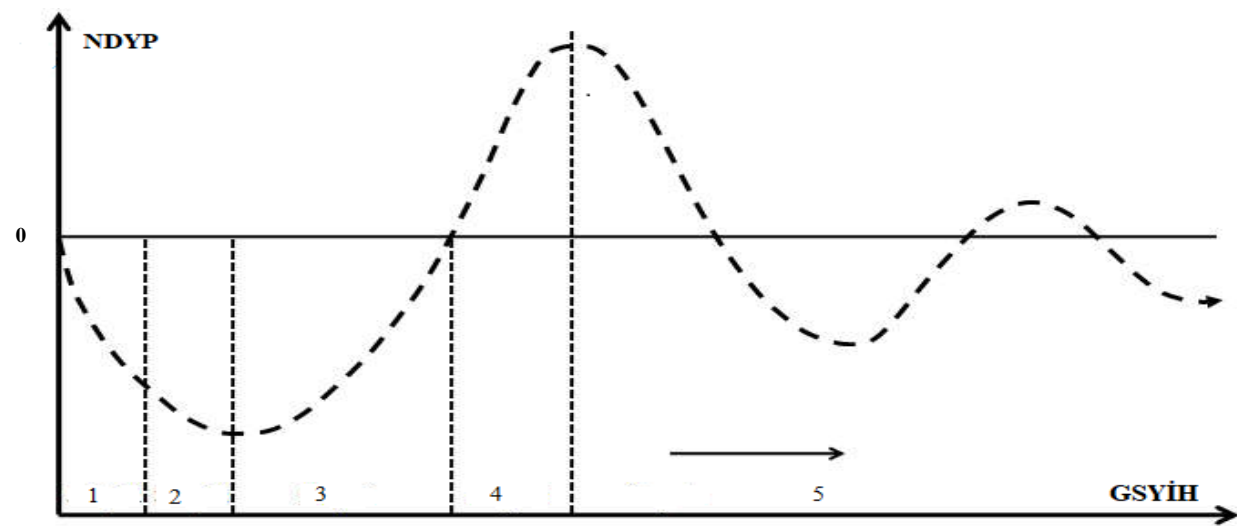

Kaynak: Dunning \& Narula, 1996: 2.

Merkezinde ülkeye gelen ve ülkeden giden doğrudan sermaye yatırımları arasındaki dinamik ilişkinin bulunduğu Yatırım Gelişme Yolu Yaklaşımı, bir ülkenin net doğrudan yabancı yatırım pozisyonunun söz konusu ülkenin gelişmişlik seviyesi ile ilişkili olduğunu göstermektedir. Bu kapsamda ülkenin net doğrudan yatırım pozisyonunu ifade eden yatırım gelişme yolu eğrisinin şeklinin zaman serisi, yatay kesit ve panel verileri kullanan ampirik çalışmaların konusu haline geldiği görülmektedir (Narula \& Dunning, 2010: 265).

Literatürde YGYY üzerine yapılan ampirik çalışmalar değerlendirildiğinde söz konusu çalışmaların ağırlıklı olarak incelenen ülke/ülke gruplarının YGYY'nda öngörülen ekonomik gelişme aşamalarının hangisinde bulunduğunun incelenmesine ve/veya ülkeler arasında karşılaştırmalar yapılmasına yönelik olduğu görülmektedir. Söz konusu ampirik çalışmalarda sıklıkla akım, stok, toplam akım ve ortalama akım gibi farklı DYSY göstergeleri kullanılmaktadır (Narula \& Guimon, 2010: 8). Bu kapsamdaki söz konusu uygulamalı çalışmalarda iki ana yöntem kullanıldığı görülmektedir. Yöntemlerden birincisinde, aşağıda 1 numaralı denklemde gösterildiği gibi, ülke/ülke gruplarının NDYP ile GSYİH arasındaki U-biçimindeki ilişkiyi yansıtmak üzere ikinci derece bir eşitlik yardımıyla belirlenilmesine çalışılmaktadır (Dunning \& Narula, 1996; Barry vd., 2002; Kula, 2003). 


$$
N D Y P=\beta_{0}+\beta_{1} G S Y I H+\beta_{2} G S Y I H^{2}+\varepsilon
$$

İkinci derecede eşitliklerin yanında ampirik literatürde, ülkelerin yatırım gelişme yolundaki pozisyonlarına bağlı olarak farklı denklemler de tahmin edilebilmektedir. Örneğin Buckley ve Castro (1998), Portekiz üzerine yaptığı çalışmada birinci aşamada FDI büyüme hızının GSYİH büyüme hızından yüksek olduğu durumda aşağıda 2 numaralı denklemde gösterildiği üzere, ikinci dereceden fonksiyonel formdan ziyade daha yüksek dereceli bir polinomun daha uygun bir eşitlik olacağını savunmaktadır. Bunun yanında Bellak (2001)'de Avusturya üzerine yapılan çalışmada ise aşağıda 3 numaralı denklemde gösterildiği üzere dördüncü dereceden bir polinom kullanıldığı görülmektedir.

$$
\begin{aligned}
& N D Y P=\beta_{0}+\beta_{1} G S Y I H^{3}+\beta_{2} G S Y I H^{5}+\varepsilon \\
& N D Y P=\beta_{0}+\beta_{1} G S Y I H+\beta_{2} G S Y I H^{2}+\beta_{3} G S Y I H^{3}+\beta_{4} G S Y I H^{4}+\varepsilon
\end{aligned}
$$

Ülke/ülke gruplarının YGYY'nda öngörülen aşamaların hangisinde bulunduğunun araştırıldığı çalışmaların ikinci grubunda ise Doğrudan Yabancı Sermaye Yatırımları Çıkışı Performans Endeksi (Outward Foreign Direct Investment Performance Index-OPI) ve Yatırım Pozisyon Endeksi (Investment Position Index-IPI) gibi endeksler kullanılmaktadır. Söz konusu endeks değerleri yorumlanarak ülke/ülke gruplarının YGYY'nda öngörülen aşamaların hangisinde bulunduğu tespit edilmektedir.

OPI Endeks değeri, aşağıda 4 numaralı denklemde gösterildiği üzere, küresel doğrudan yabancı sermaye çıkışları içerisindeki ülke payının, yine küresel GSYİH içerisindeki ülke payına oranlanmasıyla elde edilmekte ve bir ülkenin DYSY aracılığıyla küresel ekonomide başka bir ülkeye yatırım yapma konusundaki göreceli başarısını ortaya koymaktadır. Bu kapsamda bir ülkenin küresel ODI içerisindeki payı, ülkenin küresel GSYİH içindeki payına eşit olduğunda ülkenin OPI endeksi 1 değerine eşit olmaktadır. Bir ülkenin küresel ODI içerisindeki payı, ülkenin küresel GSYİH içindeki payından daha büyük (küçük) eşit olduğunda ise ülkenin OPI endeks değeri bir değerinden büyük (küçük) bir değer almaktadır. OPI Endeks değerinin 1 değerinden büyük veya küçük olması ülkenin NDYP'nun sırasıyla pozitif veya negatif değerler aldığı anlamına gelmektedir. OPI endeksine yatırım gelişme yolundaki konumlandırma açısından bakıldığında, endeks değerinin 1 değerine yakın veya yüksek olması söz konusu ülkenin yatırım gelişme yolunda bir sonraki bir gelişme aşamasına ulaşmaya daha yakın olduğu şeklinde yorumlanmaktadır (Gorynia, vd., 2012: 81; Kosztowniak, 2018: 50-51).

$$
O P I=\left(O D I_{i-u ̈ l k e} / O D I_{\text {Dünya }}\right) /\left(G S Y \dot{\mathrm{I}} H_{i-u ̈ l k e} / G S Y \dot{I} H_{D u ̈ n y a}\right)
$$

IPI Endeks değeri ise, 5 numaralı denklemde gösterildiği gibi, NDYP'nun doğrudan yabancı sermaye girişlerine oranlanması yoluyla hesaplanmaktadır. IPI Endeks değerinin -1 ve 0 arasında değerler alması ülkenin yatırım gelişme yolu aşamalarından 2 . veya 3 . aşamasında olduğunu göstermektedir. Bu aşamada ülkeye dışardan DYSY gelmekte ve az da olsa dışarıya DYSY yapmaktadır. IPI endeks değerinin 0 değerinin üzerinde olması ise ülkenin yatırım gelişme yolu aşamalarından 4. aşamada olduğu ve net doğrudan yatırım 
Yazgan, Ş. \& R. Ceylan \& M.Ş. Mollavelioğlu (2021), "Yatırım Gelişme Yolu

Yaklaşımı Üzerine Bir Yakınsama Analizi”, Sosyoekonomi, 29(48), 489-510.

pozisyonunun pozitif olduğu şeklinde yorumlanmaktadır. IPI endeks değerinin 1 değerinin üzerinde olması ise ülkenin yüksek hacimli net doğrudan yatırım pozisyonunun bulunduğu dışında bir şey ifade etmemektedir. Yatırım gelişme yolunun beşinci aşamasında ise IPI endeks değeri zirve değerinden düşmekte ve 0 değeri civarında dalgalanmaktadır (Ma, 2012: $83)$.

$$
I P I=(O D I-F D I) / F D I
$$

Dunning ve Narula (1996), Dünya ekonomisinin giderek küreselleşmesi ve firmalar açısından ulusal sınırların bulanıklaşması nedeniyle 1980'li yıllardan itibaren YGYY'nin temel modelinin önemli ölçüde değiştiğini ifade etmektedir. Bu bağlamda temel modelde üç önemli metodolojik problem tespit edilmekte ve yeni bir yaklaşım önerilmektedir. Söz konusu metodolojik problemlerden birincisinde, ülkelerde sıfır düzeyine yakın bir NDYP yatırım gelişme yolunun hem birinci hem de beşinci aşamasında bulunabildiği belirtilmektedir. Ayrıca, NDYP'ndaki artış genellikle ülkelerin rekabet güçlerinin artması olarak yorumlanmakla birlikte söz konusu durum ülkeye gelen FDI miktarında yüksek oranlı bir düşüşe bağlı olarak da ortaya çıkabilmektedir. İkinci metodolojik problemde ülkenin gelişmişlik seviyesinin belirlenmesinde kişi başına GSYİH'nın yetersiz bir gösterge olduğu ifade edilmektedir. Üçüncü olarak ise, modellerin test edilmesinde kullanılan ekonometrik araçlar yeterli bulunmamaktadır. Bu kapsamda özellikle birinci metodolojik problemin üstesinden gelinmesi için Duran ve Ubeda (2001), GSYİH/kişi başına GSYİH'dan bağımsız olarak NDYP yanında ODI ve FDI'nın kullanıldığı yeni bir grafiksel gösterim önermektedir Ülkelerin yatırım gelişme yolu aşamalarının bu yeni yöntemle temsilinin DYSY dinamiklerinin daha iyi bir şekilde yorumlanmasına olanak sağlayacağı ileri sürülmektedir (Duran \& Ubeda, 2001: 16-17; Fonseca vd., 2007: 9-12).

$\mathrm{Bu}$ açıklamaların yanı sıra, literatürdeki ampirik çalışmalarda genellikle yatırım gelişme yolu aşamalarını birbirinden ayıran parametre olarak sadece ülkenin net doğrudan yatırım pozisyonu ve GSYİH'sı arasındaki ilişkinin kullanıldığı görülmektedir. Ancak, Narula ve Dunning (2010), ülkenin net doğrudan yatırım pozisyonundaki değişimler yanında ülkeye gelen ve ülkeden giden doğrudan sermaye yatırımlarının karakteristikleri, firmaların sahiplik ve ülkelerin konumsal üstünlükleri, yapısal dönüşüm gibi diğer faktörlerin Yatırım Gelişme Yolu Yaklaşımında öngörülen iktisadi gelişme aşamalarında farklılaşabileceğini ifade etmektedir (Narula \& Dunning, 2010: 267-268).

Bu kapsamda çalışma, literatürdeki çalışmalardan iki yönden farklılaşmaktadır. İlk olarak, incelenen ülke gruplarına ait yatırım gelişme yolu eğrileri, ilgili literatürdeki çalışmaların büyük bir kısmından farklı olarak ve Duran ve Ubeda (2001)'nın çalışmalarından esinlenerek fakat daha farklı bir ifadeyle ülke gruplarına ait ODI ve FDI miktarlarının birbirlerine oranlanması yoluyla elde edilmektedir. Burada Duran ve Ubeda (2001) tarafından ileri sürülen görüşlere ek olarak, gelişmiş ve gelişmekte olan ülkeler için ayrı ayrı hesaplanan ODI ve FDI miktarlarının birbirlerine oranlarının, ülkelere gelen ve giden yatırımların nasıl seyrettiğini gösteren bir araç olmasının yanı sıra ülkelerin yatırım ortamına ilişkin güçlü bir gösterge olduğu düşünülmektedir (TEPAV, 2019: 2). İkinci olarak 
çalışmada, gelişmiş ve gelişmekte olan ülkeler olarak toplulaştırılan ülke gruplarının YGYY'nda öngörülen aşamaların hangisinde bulunduğu araştırılmamakta, bunun yerine söz konusu ülke gruplarına ait ODI ve FDI miktarlarının birbirlerine oranlanması yoluyla elde edilen yatırım gelişme yolu eğrilerinin birbirlerine yakınsayıp yakınsamadıkları zaman serisi analizi kapsamında doğrusal olmayan birim kök testleri kullanılarak ekonometrik olarak incelenmektedir. Söz konusu iki yönüyle literatürdeki çalışmalardan farklılaşan çalışmanın ilgili ampirik literatürün gelişimine katkı sağlayacağı değerlendirilmektedir.

\section{Araştırmanın Verileri ve Ekonometrik Metodolojisi}

Çalışmada kullanılan, dünyanın farklı kıtalarında konumlanan ve Birleşmiş Milletler Ticaret ve Kalkınma Konferansı (UNCTAD) tarafından gelişmiş ve gelişmekte olan ülkeler olarak toplulaştırılan ülke grupları için ODI ve FDI verileri UNCTAD'dan elde edilmektedir (UNCTAD, 2020). Bu kapsamda çalışmada 41'i gelişmiş ülke, 159'u ise gelişmekte olan olmak üzere toplam 200 ülkeye ait toplulaştırılmış ODI ve FDI verisi kullanılmaktadır. İnceleme dönemi olan 1970-2018 yılları arasında küresel ODI ve FDI'nın seyri aşağıda Şekil 2'de gösterilmektedir.

Şekil: 2

Küresel ODI ve FDI'nın Seyri (1970-2018)

2500000

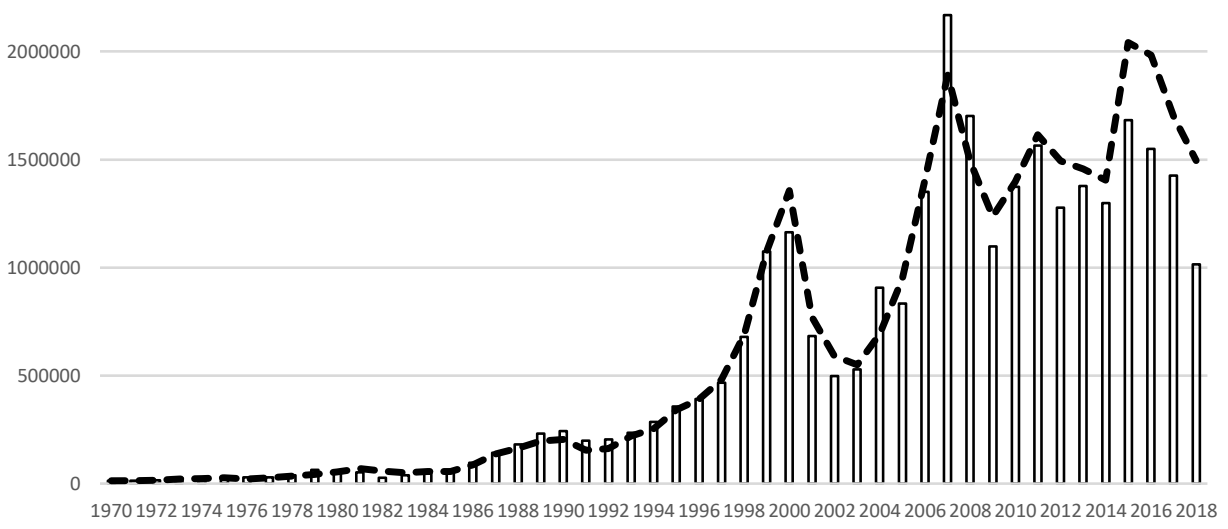

Küresel ODI - - - Küresel FDI

Kaynak: UNCTAD (2020) DYSY istatistikleri kullanılarak yazarlar tarafindan oluşturulmuştur.

Küresel ODI boyutuyla ülkeden çıkan doğrudan yabancı sermaye yatırımlarının 1980'lerden sonra önemli ölçüde arttığı görülmektedir. 1970 yılında 14 milyar dolar seviyesinde bulunan küresel ODI, 1980 yılından sonra yaklaşık 4 kat artarak 50 milyar dolar seviyesine ulaşmakta ve 2000'li yıllara gelindiğinde ise 1 trilyon dolar seviyesini 
aşmaktadır. İnceleme döneminde küresel ODI en yüksek seviyesi olan 2,1 trilyon dolar seviyesine 2007 yılında ulaştığı ve 2008 küresel krizinin etkisiyle dalgalı bir seyir izleyerek 1 trilyon dolar seviyesine gerilediği görülmektedir. Küresel FDI açısından bakıldığında ise ülkeye giren doğrudan yabancı sermaye yatırımlarının 1970 yılında 13 milyar dolar seviyesinde bulunduğunu ve kademeli artışlarla 1980 yılında 50 milyar dolar, 2000 yılında 1,3 trilyon dolar, 2007 yılında 1,8 trilyon dolar seviyesine ulaştığ görülmektedir. Küresel FDI zirve noktası olan 2 trilyon dolar seviyesine 2015 yılında ulaşmakta ancak 2018 yılına gelindiğinde ise 1,4 trilyon dolar seviyesine gerilemektedir.

Küresel ODI ve FDI boyutuyla en dikkat çekici husus küresel ODI ve FDI'nın gelişmiş ve gelişmekte olan ülkeler arasındaki dağılımında gerçekleşmektedir. İnceleme dönemi olan 1970-2018 yılları arasında seçili yıllarda toplam FDI ve ODI'nin gelişmiş ve gelişmekte olan ülkeler arasındaki yüzde dağılımları aşağıda Tablo 1'de gösterilmektedir. Tablo1, 1970-2018 yılları arasında ODI ve FDI boyutuyla küresel DYSY coğrafyasında çok önemli değişiklikler olduğunu göstermektedir. FDI açısından bakıldığında 1970 yılında küresel FDI'nın yüzde 71,59'unun gelişmiş ülkeler, yüzde 28,41'inin ise gelişmekte olan ülkeler tarafından gerçekleştirilmekle birlikte bu rakamların 2018 yılında gelişmekte olan ülkeler lehine değişerek sırasıyla yüzde 44,1 ve yüzde 55,9 düzeylerine ulaşmaktadır. İnceleme döneminde dünyadaki DYSY'nın dağılımına ODI açısından bakıldığında ise daha dramatik değişikliklerin olduğu görülmektedir. 1970-2018 döneminde küresel ODI'nin neredeyse tamamını gerçekleştiren gelişmiş ülkelerin payının 2018 yılına gelindiğinde yüzde 57,22 seviyesine gerilediği tablodan izlenebilmektedir. 2018 yılında gelişmekte olan ülkelerin küresel ODI içerisindeki payı ise yüzde 42,78 düzeyinde bulunmaktadır. Bu rakamlar 1970'ten 2018 yılına gelindiğinde gelişmekte olan ülkelerin kaynak ülke pozisyonlarının oldukça geliştiğini göstermektedir.

\section{Tablo: 1}

\section{Seçili Yıllarda Toplam FDI ve ODI'nin Gelişmiş ve Gelişmekte Olan Ülkeler Arasındaki Yüzde Dağılımları}

\begin{tabular}{|c|c|c|c|c|c|c|}
\hline & \multicolumn{6}{|c|}{ FDI } \\
\hline Ülke Grupları & 1970 & 1980 & 1990 & 2000 & 2010 & 2018 \\
\hline Gelişmiş Ekonomiler & 71,59 & 86,40 & 83,08 & 82,85 & 52,18 & 44,10 \\
\hline Gelişmekte Olan Ekonomiler & 28,41 & 13,60 & 16,92 & 17,15 & 47,82 & 55,90 \\
\hline Dünya / Toplam & 100 & 100 & 100 & 100 & 100 & 100 \\
\hline & \multicolumn{6}{|c|}{ ODI } \\
\hline Ülke Grupları & 1970 & 1980 & 1990 & 2000 & 2010 & 2018 \\
\hline Gelişmiș Ekonomiler & 99,71 & 94,76 & 94,63 & 92,35 & 73,02 & 57,22 \\
\hline Gelişmekte Olan Ekonomiler & 0,29 & 5,24 & 5,37 & 7,65 & 26,98 & 42,78 \\
\hline Dünya / Toplam & 100 & 100 & 100 & 100 & 100 & 100 \\
\hline
\end{tabular}

Kaynak: UNCTAD (2020) DYSY istatistikleri kullanılarak yazarlar tarafindan oluşturulmuştur.

Çalışmada, gelişmiş ve gelişmekte olan ülkelerin yatırım gelişme yolu eğrileri için yakınsama hipotezinin geçerliliğinin ampirik açıdan incelenmesi amaçlanmaktadır. Burada yakınsama çıkarımının yapılması durumunda gelişmiş ve gelişmekte olan ülkelerin net yatırım pozisyonlarının birbirine benzer karakteristik özellikler taşıdığı ayrıca, bu ülkelerde bulunan firmaların rekabet güçlerinin birbirine yaklaşacağı söylenebilmektedir Bu amaçla çalışmada kullanılacak gelişmiş ve gelişmekte olan ülkelere ait yatırım gelişme yolu eğrileri 
Duran ve Ubeda (2001) çalışmasından esinlenerek fakat daha farklı bir gösterimle ülke gruplarına ait ODI ve FDI miktarlarının birbirlerine oranlanması yoluyla elde edilmektedir. Söz konusu yöntem kullanılarak yatırım gelişme yolu eğrilerinin elde edilmesi sonucunda temel YGYY modelinde öngörülen ve ülkelerin ODI ve FDI miktarlarının birbirlerine eşit olduğu durumda sıfır (0) olan eşik seviyesi artık bir (1) değeri olarak karşımıza çıkmaktadır. Aşağıda Şekil 3'te inceleme dönemi olan 1970-2018 yılları arasında gelişmiş ve gelişmekte olan ülkelerin yatırım gelişme yolu eğrilerinin seyri gösterilmektedir.

Şekil: 3

Gelişmiş ve Gelişmekte Olan Ülkelerin Yatırım Gelişme Yolu Eğrilerinin Seyri (1970-2018)
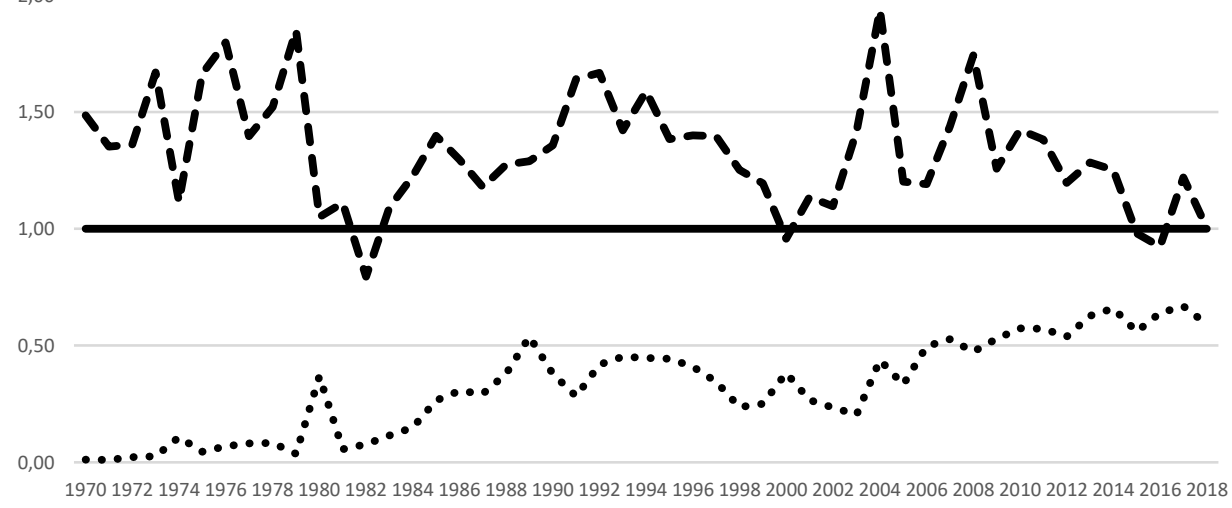

- Gelişmiş Ülkeler

•..... Gelişmekte Olan Ülkeler

Eşik Değer (ODI/FDI)

Kaynak: UNCTAD (2020) DYSY istatistikleri kullanılarak yazarlar tarafindan oluşturulmuştur.

Şekil 3 incelendiğinde, gelişmiş ülkelere ait yatırım gelişme yolu eğrisinin eşik değeri düzeyinin üzerinde bulunduğu ve YGYY'nda öngörüldüğü üzere bu düzey seviyesinde dönemsel dalgalanmalar gösterdiği tespit edilebilmektedir. Bu itibarla gelişmiş ülkelerin yatırım gelişme yolunun dördüncü veya beşinci aşamasında oldukları ifade edilebilmektedir. Şekil 3'te gösterilen gelişmekte olan ülkelere ait yatırım gelişme yolu eğrisinin ise tüm inceleme döneminde eşik değerinin altında seyrettiği görülmektedir. Bununla birlikte gelişmekte olan ülkelerin yatırım gelişme yolu eğrisinin 1970'lerde sıfır değerine yakın değerler aldığı yani yatırım gelişme yolunun birinci aşamasında bulundukları ve fakat inceleme dönemi içerisinde söz konusu oranın aşamalı olarak artışlar göstererek 2006 yılından itibaren 0,50 seviyesinin üzerinde değerler aldığ ve eşik değerine nispeten 
yaklaştığı görülmektedir. Bu durum, gelişmekte olan ülkelerin yatırım gelişme yolunun ikinci veya üçüncü aşamasında bulunduğu şeklinde değerlendirilmektedir.

Çalışmada gelişmiş ve gelişmekte olan ülkelerin net doğrudan yatırım pozisyonlarını temsil eden yatırım gelişme yolu eğrileri için yakınsama hipotezinin geçerliliği doğrusal olmayan birim kök testleriyle sınanmaktadır. Çalışmada analizde kullanılan veriler UNCTAD (2020)'den elde edilen ve 200 ülkeden toplulaştırılan ODI ve FDI değerlerinden üretilen zaman serisi kapsamında bulunmaktadır. Çalışmada analizde kullanılacak veriler aşağıda 6 numaralı denklemde gösterildiği üzere, gelişmekte olan ve gelişmiş ülkelere ait ODI ve FDI oranlarının birbirlerine bölünmesi yoluyla elde edilmektedir.

$$
D_{t}=(O D I / F D I)_{G O \ddot{U}_{t}} /(O D I / F D I)_{G \ddot{U}_{t}}
$$

Teorik açıdan gelişmekte olan ve gelişmiş ülkelere ait yatırım gelişme yolu eğrilerinin aralarındaki farklılıkların zaman içinde azalması anlamına gelen yakınsama hipotezinin geçerliliği birim kök testleriyle $\left(D_{t}\right)$ değişkeninin durağanlık durumu üzerinden araştırılmaktadır. Söz konusu değişkenin zaman içerisindeki hareketlerinin durağan özellikler sergilemesi, gelişmekte olan ve gelişmiş ülkelere ait yatırım gelişme yolu eğrilerinin birbirine yakınsadığını göstermekte ve ilgili ülke grupları için yakınsama hipotezinin ampirik açıdan geçerli olduğunu ifade etmektedir.

Çalışmada, doğrusal olmayan birim kök tekniğine dayanan birim kök testlerinden, Kapetanios vd. (2003) tarafından geliştirilen KSS doğrusal olmayan birim kök testi ve bu testin gelişmiş versiyonu olan ve Kruse (2011) tarafından geliştirilen KRUSE doğrusal olmayan birim kök testi ile Shahbaz vd. (2019) tarafından geliştirilen ve bir zaman serisinde meydana gelen keskin ve yumuşak yapısal kırılmaları, lojistik ve Fourier fonksiyonlarının birleşiminden hareketle açıklayan doğrusal olmayan SOR birim kök testi kullanılarak $\left(D_{t}\right)$ değişkeninin durağanlık durumu araştırılmaktadır ${ }^{1}$. Ancak, doğrusal olmayan zaman serisi tekniğine dayanan birim kök testlerinin kullanılabilmesi için öncelikle ele alınan seri için doğrusallık hipotezi test edilmeli ve doğrusallık hipotezinin reddedilmesi durumunda doğrusal olmayan zaman serisi tekniğine dayanan birim kök testlerinin kullanılması gerekmektedir. Bu amaçla çalışmada $\left(D_{t}\right)$ serisi için Luukkonen vd. (1988) ve Harvey vd. (2008) tarafından geliştirilen doğrusallık testleri kullanılmaktadır. Analizde kullanılan doğrusallık testlerine ilişkin teknik açıklamalar aşağıda sunulmaktadır:

Luukkonen vd. (1988) düzeyde durağan olan seriler için, aşağıda gösterilen 7 numaralı denklemin tahmin edilerek serinin doğrusallık sınamasının yapılabileceğini ileri sürmektedirler. Analizde F-tipi test istatistiği kullanılmakta, optimal gecikme uzunluğu (p) ve optimal bozucu (delay) terim (d), veri setine dayalı olarak F-istatistiğini optimize edecek şekilde seçilmektedir.

Çalışmada kullanılan söz konusu testlerin yanı sıra literatürde durağanlık sinamasında, Omay (2015), Canarella vd. (2020), Omay vd. (2020) ve Omay vd. (2021) gibi doğrusal olmayan birim kök testleri de kullanılmaktadır. 


$$
D_{t}=\theta_{o}+\left[\sum_{k=1}^{p}\left(\theta_{1 k} D_{t-k}+\theta_{2 k} D_{t-k} \cdot D_{t-d}+\theta_{3 k} D_{t-k} D_{t-d}^{2}\right)\right]+\theta_{4} D_{t-d}^{3}+v_{t}
$$

$\mathrm{Bu}$ modelde test edilecek boş hipotez: $H_{0}: \theta_{2 k}=\theta_{3 k}=\theta_{4}=0$ biçiminde ifade edilmektedir. Boş hipotezin reddedilmesi halinde serinin doğrusal olmadığına karar verilmektedir.

Harvey vd. (2008) ise düzeyde veya farkta durağan olan küçük örneklem serileri için doğrusallık testinin aşağıda gösterilen 8 numaralı denklem ile araştırılabileceğini belirtmektedirler. Analizde yine F-tipi test istatistiği kullanılmaktadır.

$$
D_{t}=\alpha_{0}+\alpha_{1} D_{t-1}+\alpha_{2} D_{t-1}^{2}+\alpha_{3} D_{t-1}^{3}+e_{t}
$$

Harvey vd., (2008) için test edilecek boş hipotez $H_{0}: \alpha_{2}=\alpha_{3}=0$ biçiminde ifade edilmekte ve boş hipotezin reddedilmesi halinde serinin doğrusal olmadığına karar verilmektedir.

Çalışmada kullanılan yatırım genişleme yolu serisine ilişkin yukarıda sözü edilen doğrusallık testlerine ait sonuçlara göre Luukkonen vd. (1988) testi için F değeri 11.04 olup $\% 1$ marjinal olasılık anlamlılık düzeyinde doğrusallık hipotezini reddetmektedir. Harvey vd. (2008) testi için de F değeri 4.89 olup \%10 anlamlılık düzeyinde doğrusallık hipotezini reddetmektedir. Bu sonuçlar analizde kullanılan yatırım gelişme yolu serisinin incelenen dönemde doğrusal olmadığını ampirik yönden ortaya koyması bakımından önemlidir. Elde edilen bu bulgular, analizde kullanılan yatırım gelişme yolu serisinin durağanlık incelemesinde doğrusal olmayan zaman serisi tekniğine dayanan birim kök testlerinin uygulanabilir olduğunu göstermesi nedeniyle önem taşımaktadır.

KSS doğrusal olmayan birim kök testinde bir serinin durağan olmadığını belirten boş hipoteze karşılık alternatif hipotez serinin durağan ve Üstel Yumuşak Geçişli Otoregresif Sürece (ESTAR) sahip olduğunu belirtmektedir. KSS birim kök testinde tanımlanan model aşağıda 9 numaralı denklemde gösterilmektedir.

$$
\Delta y_{t=} \gamma y_{t-1}\left[1-\exp \left(-\theta y_{t-1}^{2}\right)\right]+\varepsilon_{t}
$$

$\mathrm{Bu}$ modelde geleneksel ADF testinin gerçek süreç doğrusal olmadığında ve birim kök içermediğinde yeterince güçlü olmaması beklenmektedir. Ayrıca KSS testi küçük örneklemlerde de birim kökün varlığının ortaya konmasında ADF testine göre daha başarılı sonuçlar ortaya koymaktadır. Dolayısıyla, bu modeli test etmek için farklı bir test yönteminin geliştirildiği görülmektedir. Buna göre, $H_{0}: \theta=0$ ve $H_{1}: \theta \neq 0$ olarak tanımlanmaktadır. Ancak modelde, $\gamma$ parametresi sifır hipotezinde tanımlanmadığından bu testi gerçekleştirmek mümkün olmamaktadır. Bu nedenle; Luukkonen vd. (1988) çalışmasındaki gibi t testi türünde bir test geliştirilmektedir. ESTAR modeline birinci derece Taylor yaklaşımı uygulandığında elde edilen yardımcı denklem aşağıda gösterilmektedir.

$$
\Delta y_{t=} \delta y_{t-1}^{3}+\varepsilon_{t}
$$


Modelde sıfır hipotezi $\delta=0$ ve alternatif hipotez $\delta<0$ şeklinde tanımlanmakta ve $t_{N L}$ istatistiği aşağıda 11 numaralı denklemde gösterildiği şekilde hesaplanmaktadır:

$$
t_{N L}=\frac{\widehat{\delta}}{\operatorname{s.h.(\widehat {\delta })}}
$$

Modelde olası otokorelasyon sorununu çözmek için Dickey ve Fuller (1979) çalışmasında olduğu gibi bağımlı değişkeninin gecikmeleri eklenmektedir. ESTAR modeline birinci derece Taylor yaklaşımı uygulandığında elde edilen yardımcı denklemin genişletilmiş hali aşağıda gösterilmektedir:

$$
\Delta y_{t}=\sum_{j=1}^{p} \rho_{j} \Delta y_{t-j}+\gamma y_{t-1}\left[1-\exp \left(-\theta y_{t-1}^{2}\right)\right]+\varepsilon_{t} \varepsilon_{t} \sim i i d\left(0, \sigma^{2}\right)
$$

Boş Hipotez olan $\theta=0$ hipotezinin test edilebilmesi için 10 numaralı denklemden türetilen yardımcı regresyon aşağıda gösterilmektedir. Bu modelde $t_{N L}$ istatistiği ile boş hipotez $(\delta=0)$ test edilerek serinin durağanlığı incelenmektedir.

$$
\Delta y_{t}=\sum_{j=1}^{p} \rho_{j} \Delta y_{t-j}+\delta y_{t-1}^{3}+\varepsilon_{t}
$$

KRUSE doğrusal olmayan birim kök testinde ise, KSS doğrusal olmayan birim kök testinde ifade edilen ve üstel yumuşak geçiş sürecinde (ESTAR) yer alan konum parametresinin sıfıra eşit olduğu varsayımını değiştirmektedir. Bu kapsamda KRUSE birim kök testi, KSS doğrusal olmayan birim kök testinin sıfır olmayan konum parametresine izin veren genişletilmiş versiyonu olarak ifade edilmektedir. Bu kapsamda KRUSE doğrusal olmayan birim kök testi, KSS doğrusal olmayan birim kök testindeki $(c=0)$ varsayımını ortadan kaldırarak $(c \neq 0)$ varsayımı altında aşağıdaki modelin tahminini önermektedir.

$$
\Delta y_{t}=\varnothing y_{t-1}\left(1-\exp \left\{-\gamma\left(y_{t-1}-c\right)^{2}\right\}\right)+\varepsilon_{t}
$$

KSS test prosedürünü takip ederek Taylor yaklaşımı $\gamma=0$ etrafında, geçiş fonksiyonu; $G\left(y_{t-1} ; \gamma, c\right)=\left(1-\exp \left\{-\gamma\left(y_{t-1}-c\right)^{2}\right\}\right)+\varepsilon_{t}$ olmakta ve test edilecek yardımcı regresyon denklemi aşağıda 15 numaralı denklemde gösterildiği şekliyle devam etmektedir.

$$
\Delta y_{t}=\beta_{1} y_{t-1}^{3}+\beta_{2} y_{t-1}^{2}+\beta_{3} y_{t-1}+u_{t}
$$

KRUSE doğrusal olmayan birim kök testinde testin gücünün artırılabilmesi için $\beta_{3}=$ 0 düzenlemesi yapıldığında test aşağıda 16 numaralı denklemde gösterildiği şekilde ifade edilmektedir.

$$
\Delta y_{t}=\beta_{1} y_{t-1}^{3}+\beta_{2} y_{t-1}^{2}+u_{t}
$$

Burada, $\beta_{1}=\gamma \emptyset$ ve $\beta_{2}=-2 c \gamma \emptyset$ olmaktadır. Bu noktadan hareketle birim kök temel hipotezini $\left(H_{0}: \beta_{1}=\beta_{2}=0\right)$ global durağan ESTAR sürecine $\left(H_{1}: \beta_{1}<0, \beta_{2} \neq 0\right)$ karş1 test edebilmek için önerilen test istatistiği aşağıda gösterilmektedir. Söz konusu test 
istatistiği için kritik değerler Kruse (2011) çalışmasında tablolaştırılmaktadır (Güriş vd., 2016).

$$
\tau=t_{\beta^{\frac{1}{2}=0}}^{2}+1\left(\widehat{\beta_{1}}<0\right) t_{\beta_{1}=0}^{2}
$$

SOR birim kök testi ise, bir zaman serisinde meydana gelen keskin ve yumuşak yapısal kırılmaları açıklayan doğrusal olmayan birim kök testi olarak tanımlanmaktadır (Shahbaz vd.,2019). Leybourne vd., (1998), tarafından geliştirilen ve lojistik yumuşak geçişli otoregresif modele (LSTAR) dayanan birim kök testini referans alan SOR testi için iki aşamalı bir yol takip edilmektedir. Birinci aşama, genetik algoritma yoluyla kısıtlanmış doğrusal olmayan optimizasyon algoritmasının kullanılmasını içermektedir. Daha sonra ise, tercih edilen modelin deterministik bileşeni tahmin edilmekte ve kalıntıları aşağıda gösterildiği gibi A, B ve C Modelleri kullanılarak hesaplanmaktadır. Bu kapsamda, Model A, sabit terimde yapısal kırılmayı, Model B trendin yer aldığı denklemde sabitteki yapısal kırılmayı, Model C ise hem sabit ve hem de trenddeki yapısal kırılmayı dikkate almaktadır.

$$
\begin{aligned}
& \text { Model A: } \hat{\varepsilon}_{t}=y_{t}-\hat{\alpha}_{1}-\hat{\alpha}_{2} F_{t}(\hat{\gamma}, \hat{\tau}) \\
& \text { Model B: } \hat{\varepsilon}_{t}=y_{t}-\hat{\alpha}_{1}+\hat{\beta}_{1} t-\hat{\alpha}_{2} F_{t}(\hat{\gamma}, \hat{\tau}) \\
& \text { Model C: } \hat{\varepsilon}_{t}=y_{t}-\hat{\alpha}_{1}-\hat{\beta}_{1} t-\hat{\alpha}_{2} F_{t}(\hat{\gamma}, \hat{\tau})-\hat{\beta}_{2} F_{t}(\hat{\gamma}, \hat{\tau}) t
\end{aligned}
$$

İkinci aşama, Enders ve Lee (2012) tarafından hesaplanan test istatistiğini içermektedir. $\mathrm{Bu}$ aşamada en küçük kareler regresyonunda $\hat{\phi}$ ile ilişkili t-oranı hesaplanmaktadır.

$$
\hat{\varepsilon}_{t}=d(t)+\hat{\phi}_{1} \hat{\varepsilon}_{t-1}+v_{t}
$$

Burada $\mathrm{d}(\mathrm{t})$, t'nin deterministik bir fonksiyonudur ve $v_{t}, \sigma 2$ varyans ile durağan bozulmayı ifade etmektedir. Bu aşamada, $\hat{\varepsilon}_{t}$ 'nin zayıf bir şekilde bağımlı olduğuna ve başlangıç değerinin sabit olduğunun varsayıldığına dikkat etmek gerekmektedir. Eğer d (t)'nin fonksiyonel biçimi biliniyorsa, yukarıdaki denklemin doğrudan bir birim kökün yokluk hipotezini test ettiği tahmin edilebilmektedir $(\varnothing=1)$. Ancak d (t)'nin fonksiyonel biçimi bilinmiyorsa, bu durumda; eğer $\mathrm{d}(\mathrm{t})$ yanlış belirtilirse herhangi bir test $(\emptyset=1)$ için problem teşkil edebilmektedir. Bu aşamada, Fourier genişlemesi kullanılarak d(t)'yi elde etmek mümkün olabilmektedir:

$$
d(t)=\alpha_{0}+\sum_{k=1}^{n} \alpha_{k} \sin \left(\frac{2 \pi k t}{T}\right)+\sum_{k=1}^{n} \beta_{k} \cos \left(\frac{2 \pi k t}{T}\right), n \leq T / 2
$$

Burada yaklaştırmadaki kümülatif olayların sayısı $n$ ile temsil edilmektedir. Denklemdeki k, belirli bir frekansı, T ise gözlem sayısını göstermektedir. Doğrusal olmayan bir eğilimin olmadığı durumda tanımlama, özel bir duruma dönüşmektedir $\left(\alpha_{k}=\beta_{k}=0\right)$. $\mathrm{Bu}$ aşamada büyük bir n değeri kullanılması aşırı uyum problemine yol açabilmektedir. Bierens (1997), Gallant ve Souza (1991) ve Davies (1977) gibi çalışmalar, Fourier yaklaşımı kullanılarak ampirik olarak yumuşak kırılmanın fonksiyonel formunu göstermektedir. 
Burada, n değerinin küçük olması bu doğrusal olmayan eğilimin gelişiminin istikrarlı olmasını sağlamaktadır. Son olarak, Shahbaz vd. (2019)'dan hareketle elde edilen denklem aşağıdaki formda gösterilmektedir:

$$
\Delta \hat{\varepsilon}_{t}=\alpha_{0}+\sum_{k=1}^{n} \alpha_{k} \sin \left(\frac{2 \pi k t}{T}\right)+\sum_{k=1}^{n} \beta_{k} \cos \left(\frac{2 \pi k t}{T}\right)+\phi_{1} \hat{\varepsilon}_{t-1}+\sum_{i=1}^{p} \varphi_{k} \Delta+v_{t}
$$

Denklemde, $\hat{\varepsilon}_{t}$ 'deki durağan dinamikleri hesaba katmak, denklemin test edilmesinde bağımlı değişkenlerin gecikme değerini artırmanın yaygın bir uygulama olduğu görülmektedir. Eşzamanlı olarak, EL test istatistiği değeri Model A'da $s \tau_{\alpha}$ olarak, Model B'de $\boldsymbol{s} \boldsymbol{\tau}_{\boldsymbol{\alpha}(\boldsymbol{\beta})}$ ve Model C'de $s \tau_{\alpha \beta}$ şeklinde kullanılmaktadır. SOR birim kök testinde, göz önünde bulundurulması gereken önemli bir husus, az sayıda frekans bileşeninin ekonomik verilerde sıklıkla görülen kırılma tiplerini kopyalayıp tekrarlayamayacağı olarak ifade edilmektedir. $\mathrm{Bu}$ yönü takip etmek için, tek bir frekans bileşeni kullanan bir Fourier yaklaşımı ile başlanmaktadır. Bu sayede, yaklaşım için seçilen tek frekans " $\mathrm{k}$ " ile gösterilirken, deterministik terimin sinüzoidal bileşeninin genişliği ve yer değiştirmesi $\left(\alpha_{k}\right.$ ve $\left.\beta_{k}\right)$ ölçülmektedir. Bu nedenle, tek bir $\mathrm{k}=1$ frekansında bile birden fazla yumuşak kırılmaya izin verilmektedir. Fourier dönüşümü ile A, B ve C modellerine dayanan birim kök testi hipotezi aşağıdaki biçimde ifade edilebilmektedir:

$$
\begin{array}{ll}
\mathrm{H}_{0}: \text { Birim Kök } & \text { Doğrusal Durağan olmayan } \\
\begin{array}{l}
\mathrm{H}_{1}: \text { Doğrusal Olmayan } \\
\text { Durağan }
\end{array} & \text { Keskin ve Yumuşak Trendleri Eş Zamanlı Değiştiren } \\
\text { Doğrusal Olmayan ve Durağan }
\end{array}
$$

\section{Araştırmanın Bulguları}

Çalışmada, gelişmekte olan ve gelişmiş ülkelere ait yatırım gelişme yolu eğrilerinin yakınsama davranışını belirlemek üzere hesaplanan $\left(D_{t}\right)$ değişkeninin doğrusal olmadığı sonucunun elde edilmesinden sonra, durağanlık durumunu araştıran KSS, KRUSE ve SOR birim kök testlerinin bulguları sırasıyla Tablo 2 ve Tablo 3 'te sunulmaktadır. Tablo 2'de sunulan KSS ve KRUSE birim kök test sonuçları değerlendirildiğinde, KRUSE birim kök testinde yüzde 5 , KSS birim kök testinde ise yüzde 10 anlamlılık düzeyinde $\left(D_{t}\right)$ değişkeninin birim köklü olduğunu ifade eden temel hipotezin reddedildiği ve $\left(D_{t}\right)$ serisinin birim kök içermediği ve söz konusu değişkenle ifade edilen serinin durağan olduğu görülmektedir. Bu iki test sonucuna göre gelişmekte olan ve gelişmiş ülkelere ait yatırım gelişme yolu eğrileri için yakınsama hipotezi kabul edilmektedir.

\section{Tablo: 2}

\section{KSS, KRUSE Birim Kök Test Sonuçları}

\begin{tabular}{|l|c|c|c|}
\hline \multicolumn{2}{|c|}{} & KSS & $11.0886^{* *}$ \\
\cline { 2 - 4 } & $\% 1^{*}$ & $-2.9043^{* * *}$ & 13.75 \\
\cline { 2 - 4 } Kritik Değerler & $\% 5^{* *}$ & -3.48 & 10.17 \\
\cline { 2 - 4 } & $\% 10^{* * *}$ & -2.93 & 8.60 \\
\hline
\end{tabular}


SOR birim kök testi için Model A, Model B ve Model C için test sonuçları ise aşağıda Tablo 3'te gösterilmektedir. Tablo.3'te sunulan SOR birim kök test sonuçları değerlendirildiğinde Model A yüzde 10, Model B ve C ise yüzde 1 anlamlılık düzeyinde $\left(D_{t}\right)$ değişkeninin birim köklü olduğunu ifade eden temel hipotezin reddedildiği ve $\left(D_{t}\right)$ serisinin birim kök içermediği ve söz konusu değişkenle ifade edilen serinin durağan olduğu görülmektedir. Tablo 3'te sunulan göstergelerden Model A, Model B ve Model C'de gösterilen sırasıyla ortalaması $\tau=0.90, \tau=0.53$ ve $\tau=0.62$ eşik değerleri, rejim değişikliği zamanını ifade etmektedir. Bu durum $\left(D_{t}\right)$ serisinin inceleme dönemi içerisinde sırasıyla 9/10'u, 1/2'si ve 3/5'i döneminde rejim değişikliğinin gerçekleştiğini göstermektedir. Kırılma parametreleri olan $\overline{\boldsymbol{\alpha}}_{2}$ değerlerine bakıldığında bu değerin oldukça düşük olduğu tespit edilebilmektedir. Model A, Model B ve Model C'deki kırılma değerlerinin sırasıyla$0.3445,2.7717$ ve 3.5896 düzeyinde olduğu görülmektedir. Tablo 3 'te görülen Gama $(\boldsymbol{\gamma})$ parametresi rejimler arasındaki geçiş hızını vermektedir. Model A için geçiş hızı 0.1 iken Model B ve Model C için 0.2 düzeyinde bulunan gama geçiş parametresi değerinin düşük bir düzeyde bulunduğu görülmektedir.

Tablo: 3

SOR Birim Kök Testi Sonuçları

\begin{tabular}{|c|c|c|c|c|c|}
\hline \multicolumn{6}{|c|}{ Model A } \\
\hline t-istatistiği & $\bar{\alpha}_{2}$ & $\tau$ & $\gamma$ & $\alpha_{k}$ & Sıklık \\
\hline$-4.5892 * * * *$ & -0.3445 & 0.9 & 0.1 & 0.0401 & 3 \\
\hline \multicolumn{6}{|c|}{ Model B } \\
\hline t-istatistiği & $\overline{\boldsymbol{\alpha}}_{2}$ & $\tau$ & $\gamma$ & $\alpha_{k}$ & Sıklık \\
\hline$-6.2873^{*}$ & 2.7717 & 0.5 & 0.2 & -0.0019 & 3 \\
\hline \multicolumn{6}{|c|}{ Model C } \\
\hline t-istatistiği & $\overline{\boldsymbol{\alpha}}_{2}$ & $\tau$ & $\gamma$ & $\alpha_{k}$ & Sıklık \\
\hline$-6.1218^{*}$ & 3.5896 & 0.62 & 0.2 & -0.0018 & 3 \\
\hline
\end{tabular}

Not: SOR birim kök testi kritik değerleri \% $\%$, \% $5^{* *}$ ve \%10*** için strastyla, $-5.361,-4.794$ ve -4.450 şeklinde hesaplanmaktadir (Shahbaz vd., 2019).

Tablo 2 ve Tablo 3'teki bulgular birlikte analiz edildiğinde KSS, KRUSE ve SOR birim kök testlerinin gelişmekte olan ve gelişmiş ülkelere ait yatırım gelişme yolu eğrilerinin yakınsama düzeyi konusunda birbiriyle uyumlu sonuçlar ortaya çıkardığ 1 ve gelişmekte olan ülkelerin yatırım gelişme yolu eğrisinin gelişmiş ülkelerin yatırım gelişme yolu eğrisine yakınsadığı görülmektedir. Bu sonuç, yatırım gelişme yolunun temel bileşeni olan ODI ve FDI'nin ülkeler arasındaki iktisadi gelişmişlik farklılıklarının giderilmesinde önemli bir unsur olduğunu ortaya koyması bakımından önemlidir. Ayrıca, DYSY'nın küreselleşme sürecinin ayrılmaz bir parçası olduğu gerçeğinden hareketle, yakınsama çıkarımının güçlü bir şekilde vurgulanabileceği açık bir şekilde ifade edilebilmektedir.

\section{Sonuç}

Ülkelerin iktisadi gelişme sürecinde yaşadığı ekonomik ve sosyal dönüşümleri ülkeye giren ve ülkeden çıkan doğrudan yabancı sermaye yatırımları penceresinden değerlendiren YGYY, ülkelerin gelişmişlik düzeyi ile net doğrudan yatırım pozisyonu arasındaki sistematik ilişkiyi ortaya koymaktadır. YGYY'na göre ülkeler en az gelişmiş ülke konumundan gelişmiş ülke konumuna beş farklı gelişme aşamasından geçerek 
Yazgan, Ş. \& R. Ceylan \& M.Ş. Mollavelioğlu (2021), "Yatırım Gelişme Yolu

Yaklaşımı Üzerine Bir Yakınsama Analizi”, Sosyoekonomi, 29(48), 489-510.

ulaşmaktadırlar. Buna göre en az gelişmiş ülkeler tipik olarak yatırım gelişme yolunun birinci aşamasında, gelişmekte olan ülkeler ikinci veya üçüncü ve gelişmiş ülkeler ise yatırım gelişme yolunun dördüncü veya beşinci aşamasında yer almaktadır. YGYY'na göre ülke birinci aşamadan beşinci aşamaya ulaştığında net doğrudan yatırım pozisyonu bakımından ev sahibi ülke konumundan kaynak ülke konumuna doğru evrilmektedir. Söz konusu yaklaşıma göre ülkelerin aşamalar içerisinde ve aşamalar arasındaki ilerlemeleri "otomatik" bir şekilde gerçekleşmemekte ve ülkeler aşamalar arasında hem ileri hem de geri hareket edebilmektedirler Bu çerçeve içerisinde, merkezini ODI ve FDI arasındaki dinamik ilişkinin oluşturduğu YGYY, bir ülkenin net doğrudan yabancı yatırım pozisyonunun söz konusu ülkenin gelişmişlik seviyesi ile ilişkili olduğunu ve ülkenin net doğrudan yatırım pozisyonunu ifade eden Yatırım Gelişme Yolu Eğrisinin " $U$ ” biçiminde olduğunu ifade etmektedir.

1970’li yıllardan günümüze gelişmekte olan ülkelerin, küresel FDI ve özellikle de ODI'den aldıkları payları önemli ölçüde artırdıkları, başka bir ifadeyle gelişmekte olan ülkelerin doğrudan yabancı sermaye yatırımları açısından sermaye ithal eden (ev sahibi) ülke konumlarının yanına sermaye ihraç eden (kaynak) ülkeler konumu da ekledikleri görülmektedir. Bu kapsamda çalışmada söz konusu bu sürecin gelişmiş /gelişmekte olan ülkelerin net doğrudan sermaye yatırım pozisyonları yani yatırım gelişme yolu eğrileri arasındaki yakınsama davranışı üzerindeki etkisinin araştırılması amaçlanmaktadır.

Bu kapsamda çalışmada, gelişmiş ve gelişmekte olan ülkelerin net doğrudan yatırım pozisyonlarını temsil eden yatırım gelişme yolu eğrileri için yakınsama hipotezinin geçerliliği, doğrusal olmayan birim kök testleri kullanılarak zaman serisi kapsamında 19702018 dönemi için ekonometrik açıdan incelenmektedir. Bu amaçla çalışmada ilk aşamada, inceleme konusu seri için Luukkonen vd. (1988) ve Harvey vd. (2008) tarafından geliştirilen doğrusallık testleri kullanılmakta ve serinin doğrusal olmadığı sonucunun elde edilmesinden sonra, ikinci aşamada serinin durağanlık durumu KSS, KRUSE ve SOR doğrusal olmayan birim kök testleriyle araştırılmaktadır. Söz konusu birim kök test sonuçları, gelişmekte olan ve gelişmiş ülkelere ait yatırım gelişme yolu eğrilerinin doğrusal olmayan bir yapıda yakınsama davranışı sergilediğini ve dolayısıyla yakınsama sürecinin makroekonomik şoklardan etkilendiğini göstermektedir.

Çalışmada elde edilen bu sonuçlar, YGYY çerçevesinde tanım gereği yatırım gelişme yolunun ikinci veya üçüncü aşamasında bulunan gelişmekte olan ülkeler ile yatırım gelişme yolunun dördüncü veya beşinci aşamasında bulunan gelişmiş ülkelerin net doğrudan yatırım pozisyonları arasında bir yakınsama sürecinin bulunduğunu ifade etmektedir. Söz konusu bu yakınsama süreci içerisinde gelişmekte olan ülkelerin net yatırım pozisyonlarının iyileşme sürecine girdiği ve bu ülkelerin kaynak ülke konumuna doğru evrildikleri görülmektedir. Bu sonuçlar, ülkelerin ekonomik ve sosyal dönüşümünün ülkeye giren ve ülkeden çıkan doğrudan yabancı sermaye yatırımlarının davranışlarıyla sistematik bir ilişki içerisinde olduğunu ileri süren YGYY'nın öngörüleriyle örtüştüğü şeklinde değerlendirilmektedir. 
Yatırım Gelişme Yolu Yaklaşımı kapsamında ilerde yapılacak çalışmalarda, çalışmada olduğu gibi, ülkelerin net doğrudan yatırım pozisyonundaki değişimler yanında, ülkelerdeki ODI ve FDI'lerin karakteristikleri, söz konusu ülke gruplarında bulunan firmaların sahiplik yapıları ve ülkelerin konumsal üstünlükleri ve yapısal dönüşüm gibi yatırım gelişme yolu aşamaları arasındaki farklılaşan diğer faktörlerin de araştırılmasının, çalışmada tespit edilen yakınsama sürecinin daha iyi anlaşılmasına yardımcı olacağı ve literatüre katkı sağlayacağı düşünülmektedir.

\section{Kaynaklar}

Apergis, N. (2009), "Foreign Direct Investment Inward and Outward; Evidence from Panel Data, Developed and Developing Economies, and Open and Closed Economies", The American Economist, 54(2), 21-27.

Barro, R.J. (1991), "Economic Growth in a Cross Section Countries", The Quarterly Journal of Economics, 106, 407- 443.

Barro, R.J. \& X. Sala-i-Martin (1992), “Convergence”, Journal of Political Economy, 100, 223-251.

Barry, F. \& H. Görg \& A. McDowell (2002), “Outward FDI and the Investment Development Path of a Late-Industrializing Economy: Evidence from Ireland”, Regional Studies, 37, 341349 .

Bellak, C. (2001), “The Austrian Investment Development Path", Transnational Corporations, 10, 107-134.

Bernard, A.B. \& S.N. Durlauf (1995), "Convergence in International Output”, Journal of Applied Econometrics, 10(2), 97-108.

Bierens, H.J. (1997), “Nonparametric Cointegration Analysis”, Journal of Econometrics, 77(2), 379404.

Buckley, P.J. \& F.B. Castro (1998), "The Investment Development Path: the Case of Portugal”, Transnational Corporations, 7, 1-15.

Canarella, G. \& R. Gupta \& S.M. Miller \& T. Omay (2020), "Does real UK GDP have a Unit Root? Evidence from a Multi-Century Perspective”, Applied Economics, 52(10), 1070-1087.

Ceylan, R. (2010), "Yakınsama Hipotezi: Teorik Yaklaşımlar”, Sosyoekonomi, 11(11), 47-60.

Davies, R.B. (1977), "Hypothesis Testing When a Nuisance Parameter is Present Only Under the Alternative", Biometrika, 64, 247-254.

Dunning, J.H. (1980), "Toward an Eclectic Theory of International Production-Some Empirical Tests”, Journal of International Business Studies, 11(1), 9-31.

Dunning, J. H. (1981), "Explaining the International Direct Investment Position of Countries:

Towards a Dynamic or Developmental Approach", Weltwirtschaftliches Archiv, No. 119, 30-64.

Dunning, J.H. \& R. Narula (1996), “The Investment Development Path Revisited: Some Emerging Issues", içinde: J.H. Dunning \& R. Narula (eds.), Foreign Direct Investment and Governments, Routledge, London, 1-41.

Duran, J.J. \& F. Ubeda (2001), "The Investment Development Path: A New Empirical Approach and Some Theoretical Issues", Transnational Corporations, 10(2), 1-34. 
Yazgan, Ş. \& R. Ceylan \& M.Ş. Mollavelioğlu (2021), "Yatırım Gelişme Yolu

Yaklaşımı Üzerine Bir Yakınsama Analizi”, Sosyoekonomi, 29(48), 489-510.

Enders, W. \& J. Lee (2012), “The Flexible Fourier Form and Dickey-Fuller Type Unit Root Tests”, Economic Letters, 117(1), 196-99.

Fonseca, M.R. \& A. Mendoça \& J. Passos (2007), “The Investment Development Path Hypothesis: Evidence from the Portuguese Case - A Panel Data Analysis", Technical University of Lisbon, School of Economics and Management, Department of Economics Working Papers WP 021/2007/DE, 1-29.

Fonseca, M.R. \& A. Mendoça \& J. Passos (2016), "The Paradigm of The Investment Development Path: Does it Holds for Portugal? Evidence for The Period 1990-2011”, Working Paper CEsA CSG 139/2016, 1-21.

Gallant, A. \& G. Souza (1991), “On The Asymptotic Normality of Fourier Flexible Form Estimates”, Journal of Econometrics, 50(3), 329-353.

Gorynia, M. \& J. Nowak \& P. Tarka \& R. Wolniak (2012), "Foreign Direct Investment in New EU Member States from Central and Eastern Europe An Investment Development Path, Perspective", içinde: M. Marinov \& S. Marinova (eds.), Internationalization of Emerging Economies and Firms, Palgrave Macmillan, 64-86.

Gorynia, M. \& J. Nowak \& P. Trąpczyńskia \& R. Wolniak (2019), "Friend or Foe? On the Role of Institutional Reforms in the Investment Development Path of Central and East European Economies", International Business Review, 28(3), 575-587.

Güriş, B. \& B.Y. Tıraşoğlu \& M. Tıraşoğlu (2016), “Türkiye'de Satın alma Gücü Paritesi Geçerli mi?: Doğrusal Olmayan Birim Kök Testleri”, Social Sciences Research Journal, 5(1), $30-42$.

Harvey, D.I. \& S.J. Leybourne \& B. Xiao (2008), “A Powerful Test for Linearity When the order of İntegration is Unknown", Studies in Nonlinear Dynamics \& Econometrics, 12(3), 1-24.

Kapetanios, G. \& Y. Shin \& A. Snell (2003), "Testing for a Unit Root in the Nonlinear STAR Framework", Journal of Econometrics, 112, 359-379.

Kılıçaslan, Y. \& Y. Gürel-Üçdoruk \& G. Önder \& Z. Önder-Karal (2018), Türkiye'nin Yurt Dışı Yatırımları Neden? Nereye? Nasıl?, Ankara: Efil Yayınevi.

Kılıçaslan, Y. \& Y. Gürel-Üçdoruk \& G. Önder \& Z. Önder-Karal (2019), "Why Do Turkish Firms Go Abroad to Invest?", EconWorld Working Paper Series, No: 2019-001.

Kosztowniak, A. (2018), "Changes of Inward and Outward FDI Stocks in Poland and the Stage of the Investment Development Path", Journal of Management and Financial Sciences (JMFS), Vol XIII, No. 35, 41-60.

Kruse, R. (2011), “A New Unit Root Test Against ESTAR Based on a Class of Modified Statistics”, Statistical Papers, 52, 71-85.

Kula, F. (2003), "Yatırım Gelişme Yolu Yaklaşımı: Teori ve Türkiye Üzerine Ampirik Gözlemler", Atatürk Üniversitesi İktisadi ve İdari Bilimler Dergisi, 17, 57-78.

Leybourne, S. \& P. Newbold \& D. Vougas (1998), "Unit roots and smooth transitions", Journal of Time Series Analysis, 19, 83-97.

Luukkonen, R. \& P. Saikkonen \& T. Teräsvirta (1988), "Testing Linearity Against Smooth Transition Autoregressive Models", Biometrika, 75(3), 491-499.

Ma, K. (2012), “An Empirical Analysis on Chinese Outward FDI Development Path Based on IDP and IPI Models", Contemporary Logistics, 06, 81-85.

Narula, R. (1996), Multinational Investment and Economic Structure, Routledge, London. 
Narula, R. \& J. Guimon (2010), “The Investment Development Path in A Globalised World: Implications For Eastern Europe”, Eastern Journal of European Studies, 1(2), 5-19.

Narula, R. \& J.H. Dunning (2010), "Multinational Enterprises, Development and Globalization: Some Clarifications and a Research Agenda", Oxford Development Studies, 38(3), 263287.

Nelson, C.R. \& C.I. Plosser (1982), "Trends and Random Walks in Macroeconomics Time Series: Some Evidence and Implications", Journal of Monetary Economics, 10, 139-162.

Omay, T. \& B. Ozcan \& M. Shahbaz (2020), "Testing the Hysteresis Effect in The US State-level Unemployment Series", Journal of Applied Economics, 23(1), 329-348.

Omay, T. \& F. Emirmahmutoglu \& S.J. Hussain-Shahzad (2021), "Comparison of Optimization Algorithms For Selecting The Fractional Frequency in Fourier Form Unit Root Tests", Applied Economics, 53(7), 761-780.

Omay, T. (2015), "Fractional Frequency Flexible Fourier form to Approximate Smooth Breaks in Unit Root Testing", Economics Letters, 134, 123-126.

Shahbaz, M. \& T. Omay \& D. Roubaud (2019), “The Sharp and Smooth Breaks Unit Root Testing of Renewable Energy Consumption: The Way Forward", The Journal of Energy and Development, 44(1/2), 5-40.

TEPAV (2019), “Türkiye’ye Gelen ve Türkiye'den Giden Doğrudan Yatırımlardaki Gelişmeler”, TEPAV Bültenler, Ağustos, S. 15.

UNCTAD (2020), <https://unctadstat.unctad.org/wds/TableViewer/tableView.aspx?Reportld=96740>, 13.07.2020.

\section{EKLER:}

Ek: 1

UNCTAD Sınıflamasına Göre Gelişmiş Ülkeler (Kıtalara Göre)

\begin{tabular}{|c|c|}
\hline \multicolumn{2}{|c|}{ AVRUPA } \\
\hline Avusturya & İrlanda \\
\hline Belçika & İtalya \\
\hline Bulgaristan & Letonya \\
\hline Hirvatistan & Litvanya \\
\hline Kibris & Lüksemburg \\
\hline Çekya & Malta \\
\hline Çekoslovakya & Hollanda \\
\hline Danimarka & Norveç \\
\hline Estonya & Polonya \\
\hline Finlandiya & Portekiz \\
\hline Fransa & Romanya \\
\hline Almanya & Slovakya \\
\hline Almanya, Federal Cumhuriyeti & Slovenya \\
\hline Cebelitarı & İspanya \\
\hline Yunanistan & İsveç \\
\hline Macaristan & İsviçre, Liechtenstein \\
\hline İzlanda & Birleşik Krallık \\
\hline AMERÍKA & OKYANUSYA \\
\hline Bermuda & Avustralya \\
\hline Kanada & Yeni Zelanda \\
\hline Amerika Birleşik Devletleri & \\
\hline
\end{tabular}


Yazgan, Ş. \& R. Ceylan \& M.Ş. Mollavelioğlu (2021), "Yatırım Gelişme Yolu

Yaklaşımı Üzerine Bir Yakınsama Analizi”, Sosyoekonomi, 29(48), 489-510.

\section{Ek: 2}

\section{UNCTAD Sınıflamasına Göre Gelişmekte Olan Ekonomiler (Kıtalara Göre)}

\begin{tabular}{|c|c|c|}
\hline \multicolumn{3}{|c|}{ AFRİKA } \\
\hline Cezayir & Etiyopya & Nijer \\
\hline Angola & Etiyopya (... 1991) & Nijerya \\
\hline Benin & Gabon & Ruanda \\
\hline Botsvana & Gambiya & Saint Helena \\
\hline Burkina Faso & Gana & Sao Tome ve Principe \\
\hline Burundi & Gine & Senegal \\
\hline Cabo Verde & Gine-Bissau & Seyşeller \\
\hline Kamerun & Kenya & Sierra Leone \\
\hline Orta Afrika Cumhuriyeti & Lesoto & Somali \\
\hline Çad & Liberya & Güney Afrika \\
\hline Komorlar & Libya & Güney Sudan \\
\hline Kongo & Madagaskar & Sudan \\
\hline Kongo, Demokratik Cumhuriyeti & Malawi & Sudan $(\ldots 2011)$ \\
\hline Fildişi Sahili & Mali & Tanzanya Birleşik Cumhuriyeti \\
\hline Cibuti & Moritanya & Gitmek \\
\hline Misir & Mauritius & Tunus \\
\hline Ekvator Ginesi & Fas & Uganda \\
\hline Eritre & Mozambik & Zambiya \\
\hline Svaziland'da & Namibya & Zimbabve \\
\hline \multicolumn{3}{|c|}{ AMERÍKA } \\
\hline Anguilla & Dominika & Panama \\
\hline Antigua ve Barbuda & Dominik Cumhuriyeti & Panama, Kanal Bölgesi hariç \\
\hline Arjantin & Ekvador & Paraguay \\
\hline Aruba & El Salvador & Peru \\
\hline Bahamalar & Falkland Adalar1 & Saint Kitts ve Nevis \\
\hline Barbados & Grenada & Saint Lucia \\
\hline Belize & Guatemala & Saint Vincent ve Grenadinler \\
\hline Bolivya (Çokuluslu Devlet) & Guyana & Sint Maarten (Hollanda kısmı) \\
\hline Brezilya & Haiti & Surinam \\
\hline Britanya Virjin Adaları & Honduras & Trinidad ve Tobago \\
\hline Cayman Adaları & Jamaika & Turks ve Caicos Adaları \\
\hline Şili & Meksika & Uruguay \\
\hline Kolombiya & Montserrat & Venezuela (Bolivarcı Cumhuriyeti) \\
\hline Kosta Rika & Hollanda Antilleri & \\
\hline Curacao & Nikaragua & \\
\hline \multicolumn{3}{|c|}{ ASYA } \\
\hline Afganistan & Irak & Pakistan \\
\hline Bahreyn & Ürdün & Filipinler \\
\hline Bangladeş & Kore, Dem. Halk Temsilcisi & Katar \\
\hline Butan & Kore Cumhuriyeti & Suudi Arabistan \\
\hline Brunei Darüsselam & Kuveyt & Singapur \\
\hline Kamboçya & Lao Halk Dem. Cumhuriyeti & Sri Lanka \\
\hline Çin & Lübnan & Filistin Devleti \\
\hline Çin, Hong Kong ÖİB & Malezya & Suriye Arap Cumhuriyeti \\
\hline Çin, Makao ÖİB & Maldivler & Tayland \\
\hline Çin, Tayvan Eyaleti & Moğolistan & Doğu Timor \\
\hline Hindistan & Myanmar & Türkiye \\
\hline Endonezya & Nepal & Birleşik Arap Emirlikleri \\
\hline Endonezya (... 2002) & Umman & Vietnam \\
\hline İran (İslam Cumhuriyeti) & Pakistan & Yemen \\
\hline & & Yemen, Demokratik \\
\hline \multicolumn{3}{|c|}{ OKYANUSYA } \\
\hline Cook Adaları & Nauru & Solomon Adaları \\
\hline Fiji & Yeni Kaledonya & Tonga \\
\hline Fransız Polinezyası & Kuzey Mariana Adaları & Tuvalu \\
\hline Kiribati & Palau & Vanuatu \\
\hline Marşal Adaları & Papua Yeni Gine & \\
\hline Mikronezya (Federal Eyaletler) & Samoa & \\
\hline
\end{tabular}

